\title{
Effect of tillage with injection some organic materials on power requirements for chisel plow and sandy calcareous soil productivity.
}

\author{
A. A. Meselhy \\ *Researcher in Mechanization Unit, Soil Conservation Department, Desert Research Center.
}

\begin{abstract}
This investigation was to achieve two purposes, the first to raise the distribution efficiency and effectiveness of liquid organic material (Root Plus) by being injected into the soil with the process of plowing using chisel plow where it will mix the liquid material with the soil well and at different depths, which increases the effectiveness of organic material to enrich the area of root growth in soil and leading to increase crop productivity. The second purpose to exploit the injected of liquid organic material in the soil under pressure to format a thin layer of liquid between the chisel blade surface and the soil slice, which works to ease of sliding and reduce the friction force between the chisel blade surface and the soil slice. Also using the pressure force of liquid organic material to fragment the soil slice on the blade surface, which leads to increase the degree of fragmentation of the soil and increasing the quality of the plowing and less force required to pulling the chisel plow into the soil. To achieve these goals, modifications were made to the traditional chisel plow (7 blades) so it fits the injection process of liquid organic material through the process of plowing and field experiment was carried out in a sandy calcareous soil (Ras-Sudr area) included the following treatments: Three ways to add liquid organic material (injection, spray and not added), two plowing depths (15 and $25 \mathrm{~cm})$ and three tractor forward speeds $\left(3,4\right.$ and $\left.5 \mathrm{~km} \cdot \mathrm{h}^{-1}\right)$. The obtained results from this investigation could be summarized as follows: The soil bulk density, penetration resistance and mean weight diameter (M.W.D.) were much more decreased after all treatments of tractor forward speed, tillage depth and injection liquid organic material. The soil porosity showed reverse trends as compared with the changes in the soil bulk density. Using the chisel plow for $15 \mathrm{~cm}$ depth and5km. $h^{-1}$ forward speed with injection liquid organic material gave the higher values of actual field capacity and power required to inject organic material but gave little specific cost of production. Using the chisel plow for $15 \mathrm{~cm}$ depth and $3 \mathrm{~km} \cdot \mathrm{h}^{-1}$ forward speed with injection liquid organic material gave lowest values of tractor slippage, fuel consumption, power required for pulling plow and total power (power required for pulling plow plus power required to inject organic material). Using the chisel plow at $25 \mathrm{~cm}$ depth and5km. $\mathrm{h}^{-}$ ${ }^{1}$ forward speed with no adding organic material gave the higher values of tractor slippage, fuel consumption, power required for pulling plow and total power. The higher value of wheat grain yield achieved when using the chisel plow at $25 \mathrm{~cm}$ depth and $5 \mathrm{~km} . h^{-1}$ forward speed with injection liquid organic material but the lowest value of specific cost of production achieved when using the chisel plow at $15 \mathrm{~cm}$ depth and $5 \mathrm{~km} . \mathrm{h}^{-1}$ forward speed with injection liquid organic material. On the other hand, the obtained results at $25 \mathrm{~cm}$ plowing depth and forward speed $5 \mathrm{~km} . \mathrm{h}^{-1}$ with injection liquid organic material were achieved the pest values of soil physical properties, the highest values of wheat grain yield and the specific cost was closely to those obtained at $15 \mathrm{~cm}$ plowing depth and forward speed $5 \mathrm{~km} . \mathrm{h}^{-1}$ withinjection liquid organic material. Therefore, we can be recommended that using of chisel plow at $25 \mathrm{~cm}$ depth and $5 \mathrm{~km} . \mathrm{h}^{-1}$ forward speed with injection liquid organic material for seedbed wheat production under the conditions of this experiment.
\end{abstract}

Keywords: chisel plow, power requirements, soil physical properties, injection organic materials,

\section{Introduction}

Water-jet assist reduces drawbar pull and increases plowing rate because the following:

Weakening soil structural resistance by introducing a number of slots that alter the slip-line field in favor of power reduction, lubricating the blade sides and front to reduce frictional forces, improving the flow characteristics of soil around the blade and facilitating penetration by moisturizing the soil Moodie (1976). McKyes et al. (1977) reported that injector at $15 \mathrm{~cm}$ depth and $8 \mathrm{~km} / \mathrm{h}$ required a draft of 2 to $6 \mathrm{kN}$ for soils varying in texture from loose sand to medium clay loam. Kuzmich and Rutherberg (1978) showed that waterjet assist improves equipment performance an average of 30\% to 45\%. Stafford (1979) found that draft force is influenced by speed and moisture contents. For example, at low moisture content, draft force increased with speed, while at high moisture content, the draft force decreased with speed. Araya (1980) reported that the power requirements for sub-soiler reducing more efficiently by introducing fluid under pressure from chisel blade to break down soil layer. Araya et al., (1981) and (1982) (a) showed that the draft and the power required for sub-soiling could be reduced when water, air or water-dissolved air was introduced into the soil under 
pressure from the tip of the sub-soiler chisel. The fluid broke down the soil structure in front of the sub-soiler, permitting the sub-soiler to operate in looser soil conditions. Araya (1985) found that injected a fluid from the tip of a sub-soiler to loosen the soil structure in front of the tool and also lubricate the tool-soil interface. After taking into account of the power required for injecting the fluid, a total saving in energy per unit volume of $30 \%$ was recorded. Qian and Zhang (1984) estimated up to 50\% of the gross energy consumed by tillage operation is to overcome the adhesion and friction between soil and tillage tools Qaisrani et al. (1992) and Qaisrani (1993) strongly supported these results. CHEN et al. (1990) showed that air or other liquid are injected at soiltool interface to improve soil scouring. The liquid acts as a lubricant and prevents adhesion of soil by aiding free flow of soil over the surface. The formation of air cushion or liquid film at soil-tool interface is helpful in reducing the contact of soil with the tools. The air and liquid injection at soil-tool interface improves the performance of the tools and requires some additional components for the application of fluid. This technique has been useful in minimizing the adhesion from the surfaces of excavators, earthmoving machinery, ploughs, etc. However, the quantity of water required as lubricant makes the technique impractical in a number of situations. For example, more than 16 liters/ha water is required to achieve a desired level of scouring from the plough surfaces. Moreover, it is better to use air as lubricant for soils which absorb large quantities of water. Negi et al. (1978) and Laguë (1991) reported that injector power ranged from $1.4 \mathrm{~kW}$ per injector at $20 \mathrm{~cm}$ depth and $4 \mathrm{~km} / \mathrm{h}$ to $5 \mathrm{~kW}$ per injector at $40 \mathrm{~cm}$ depth and $8 \mathrm{~km} / \mathrm{h}$. Kempainrn (1986); Hall (1986); Jokela and Côté (1994) mentioned that in the prairies, major concerns are odor emissions and nutrient losses associated with surface spreading. Injecting manure below the soil surface can minimize odor and ammonia emission. IGER (1995) showed that injection of manure can reduce odor emission and ammonia volatilization by about 85 and 90\%, respectively. Jokela and Côté (1994) reported that injection may be defined as the application of manure by method which incorporate the manure into the soil by some physical means (i.e. tillage operation). In 'direct incorporation', manure is directly incorporated into the soil by the injection tool itself without a separate tillage operation. Prins and Snijders (1987), cited by Misselbrook et al. (1996) addition that, surface application of manure causes smothering and scorching of the grass. Collins and Fowler (1996) found that speed produce a small but significant linear increase in draft force requirement. Collins and Fowler (1996) and Huijsmans et al. (1998) reported similar conclusions, whereas the draft force of tillage tools increases significantly when the depth of operation is increased. The draft requirements of a tillage tool is also a function of operating speed and an important criterion for evaluating the performance of a tillage tool either in field and laboratory conditions. Chen and Rahman (1999) mentioned that injection depth is an important working parameter since it influences power requirements. Soil disturbances and manure covering performance (associated with odor emission) of an injector. Salokhe et al. (1999) reported that soil adheres to the surfaces of soil engaging components of various machines and equipment. It not only affects the performance of machines and quality of work but also increases energy consumption. Enamel coated tines saved power by up to $22 \%$ when operating at $1.5 \mathrm{~km} / \mathrm{h}$ speed during the first pass as compared to uncoated tines operating under similar conditions. Hilborn (2000) showed that traditional surface application of manure is low in cost and plug resistance but requires high power. Produces odor and ammonia losses by drift, and non-uniform application of manure. Chen et al. (2000) mentioned that poor injection can still result in manure exposure on the soil surface, which causes odor emissions and nutrient losses by volatilization. Metwalli et al. (2000) found that soil bulk density decreased after tillage with mouldboard plow, chisel plow (one pass) and chisel plow (two passes) and rotary plough compared with that before tillage. They also found that mouldboard plow gave the value of soil bulk density lower than chisel plow and rotary plow. Chen (2002) developed a prototype low-draft injector which combined a chisel and $200 \mathrm{~mm}$ wide sweep to better mix manure with soil and to accommodate a high manure application rate. The injector required $3.7 \mathrm{kN}$ draft in a clay soil when operating at depth of $15 \mathrm{~cm}$ and speed of $5 \mathrm{~km} / \mathrm{h}$. The American Society of Agricultural Engineers (2004) defines an injector as an implement used to insert materials into the soil. Abdel-Aal et al. (2005) indicated that the soil bulk density and soil penetration resistance were decreased for all seedbed preparation systems, while vice versa was noticed with total porosity and void ratio.

Accordingly, it is necessary to make the efforts for increasing the tillage efficiency, reducing the power requirements at the soil preparation and increasing both of the distribution efficiency and effectiveness of liquid organic material(root plus) by injected into the soil with chisel plow. Consequently, under these considerations, to achieve these goals, modifications were made to the traditional chisel plow ( 7 blades) to fits the injection of liquid organic material with plowing; subsequently, soil physical properties, power requirements of chisel plow and effects on wheat grain yield were studied in comparison with conventional system, in this research activity.

\section{Materials And Methods}

This study was carried out at Ras-Sudr Experimental Station, South Sinai of Egypt on sandy loam calcareous soil in the winter season 2012-2013 (from November 2012 to April 2013) with an experimental area of about 2.5 feddans. Before the tillage operation directly, the average moisture content of soil surface layer (0- 
$30 \mathrm{~cm}$ ) was determined and found to be $18 \%$ (d.b.).

A. Modification of chisel plow:

Chisel plow was modified in order to be suitable for injection the liquid organic material (Root Plus) with the plowing process as shown in Figures (1\& 2).

B. Liquid organic material:

Liquid organic material (Root Plus) applied at 1 liter of organic material per 200 liters of water per feddan, the root plus contains $8 \% \mathrm{P}_{2} \mathrm{O}_{5}, 5 \% \mathrm{~K}_{2} \mathrm{O}$ and $9 \%$ free amino acids.

C. Experimental Procedure:

The following are the experimental details:

1. Experimental design:

The experiment area of about $2.5 \mathrm{fed}$. This experiment was established as a split-split plots in three replicates, divided into three main plots involved three tractor forward speeds $\left(3,4\right.$, and $\left.5 \mathrm{~km} . \mathrm{h}^{-1}\right)$. Each main plot includes two sub-plots, which involved two tillage depths $(15$ and $25 \mathrm{~cm})$. Each sub-plot includes three subsub plots, which involved three methods of adding the liquid organic material to the soil (spray method, injection method and no-adding organic material), resulted in a total of 54 plots, each of $200 \mathrm{~m}^{2}$.

Wheat seeds and planting method:

The wheat was planted in November, with a rate of $50 \mathrm{~kg} / \mathrm{fed}$ and harvested in May.

\section{Harvesting:}

Before harvesting wheat crop, three randomized samples were taken by hand from each plot using a wooden square frame $\left(1 \mathrm{~m}^{2}\right)$ as a simpler to determine the wheat yield per feddan. Finally, the wheat crop was harvested using a mounted mower and threshing by thresher. Moisture content of wheat plant at harvesting was $12 \%$ d.b.

D. Measurements:

1. Plowing depth:

Plowing depths were measured using a hand scale (ruler) at three locations in each plot. The adjacent unplowed surface was taken as a reference. The required depth was obtained by means of hydraulic system.

\section{Soil bulk density and soil porosity.}

Soil bulk density was measured using a core samples (Three replicates for each sample) and the soil porosities were calculated according to Black et al (1965) method.

3. Soil mean weight diameter ( M.W.D.).

M.W.D. was determined according to Van Bavel (1949) as follows:

M. W. D. $=\sum_{\mathrm{i}=1}^{\mathrm{i}=\mathbf{n}} \frac{\mathbf{X}_{\mathrm{i}} \mathbf{W}_{\mathrm{i}}}{\mathbf{W}_{\mathrm{T}}}$

where; $X_{i}=\frac{\varepsilon_{i-1}+\varepsilon_{i}}{2}$

Where; xi: The mean weight diameter of each fractions, ( $\mathrm{mm})$.

$\mathbf{w}_{\mathbf{i}}$ : The weight of the soil retained on $\mathrm{i}^{\text {th }}$ sieve, $(\mathrm{gm})$.

$\mathbf{w}_{\mathbf{T}}$ : The total weight of the soil retained on the sieves, (gm).

$\boldsymbol{\varepsilon}_{\mathbf{i}}:$ Sieve mesh, and

i: Number of sieves.

4. Theoretical and actual field capacity and field efficiency.

Theoretical and actual field capacity and field efficiency were calculated by using equations mentioned by kepner et al (1978).

5. Soil penetration resistance:

Soil penetration resistance was measured by a Japanese cone index penetrometer (SR-2, DIK-500)

6. Power requirements.

a- Power requirements for pulling chisel plow were measured by hydraulic dynamometer which, coupled between the two tractors with the attaching chisel plough to estimate its draught force. A considerable number of readings were taken at a time interval 10 seconds to obtain an accurate average of draught force. The hitch was always adjusted in order to keep the line of pull as horizontal as possible.

b- Power requirements for injection organic material were calculated by using equations mentioned by Araya (1980).

$P_{w}=\frac{G_{t} P_{i n f}}{\rho}+\frac{G_{t}^{3}}{2 a^{2} \rho^{2}}$

Where; $\boldsymbol{P}_{\boldsymbol{w}}$ : Power required to inject organic material, $(\mathrm{W})$.

$\boldsymbol{G}_{\boldsymbol{t}}$ : Mass flow rate of liquid,

$\boldsymbol{\rho}$ : Density of liquid,

$\boldsymbol{P}_{\text {inf }}$ : Pressure at the injection nozzle port,

$(\mathrm{kg} / \mathrm{s})$.

$\left(\mathrm{kg} / \mathrm{m}^{3}\right)$.

$(\mathrm{Pa})$, and. 
a : Cross sectional area of the nozzle port

$\left(\mathrm{m}^{2}\right)$

Table (1): Specifications of spraying machine using to inject the liquid organic material.

\begin{tabular}{l|l}
\hline \multicolumn{2}{c}{ Specifications of spraying machine } \\
\hline Tank capacity & $\mathbf{6 0 0 ~} \mathbf{L}$ \\
Power of engine & $\mathbf{7 . 5} \mathbf{~ H P}$ \\
Pressure & $\mathbf{4 0 ~} \mathbf{~ b a r}$ \\
Flow rate & $\mathbf{3 5 ~ L / m i n}$ \\
\hline
\end{tabular}
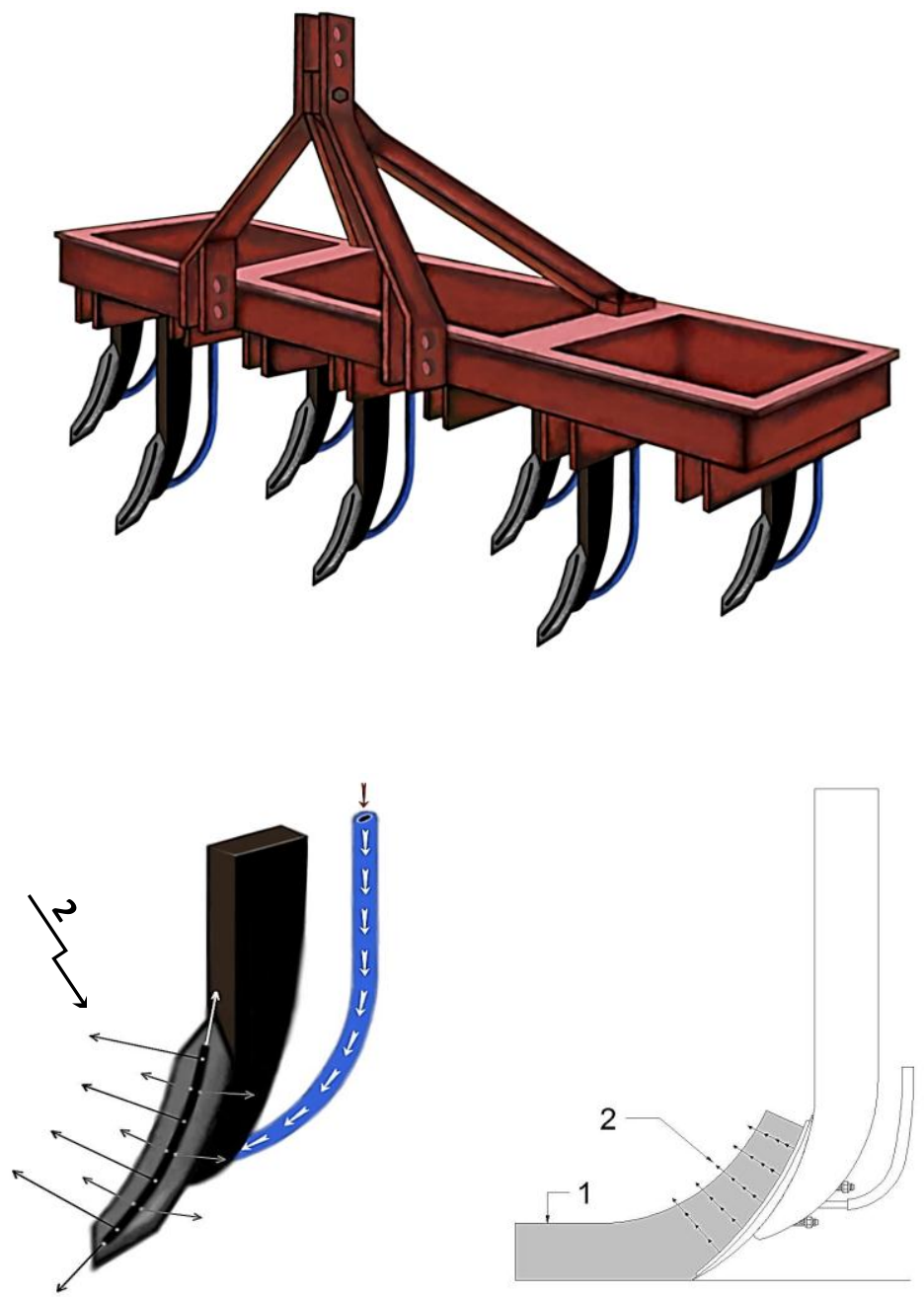

(1) Soil surface.

(2) Flow of liquid organic material on the surface of blade.

Figure (1): Method of injection liquid organic material. 


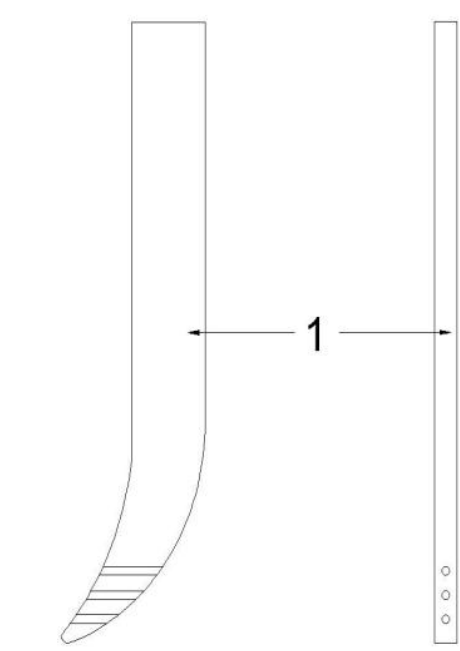

A

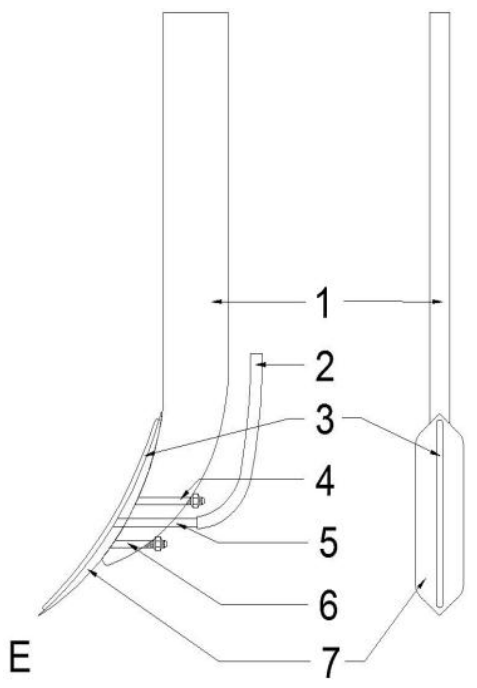

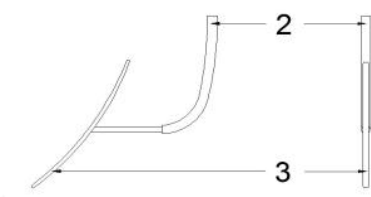

B

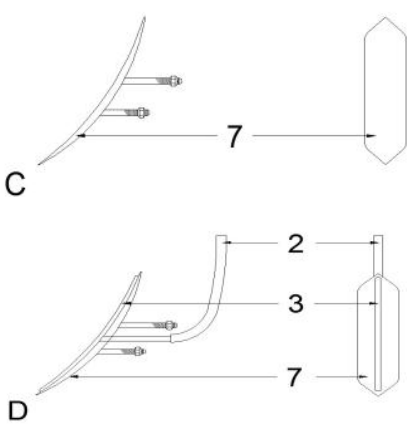

(1) Shank of chisel plow.

(2\& 5) Tube for connecting organic material to the surface of chisel blade.

(3) Tube for distribution organic material on the surface of chisel blade.

(4 \& 6) Screws for fixing the chisel blade on shank surface.

(7) The chisel blade.

Figure (2): The mechanism of injection liquid organic material.

\section{Fuel consumption rate.}

Fuel consumption per unit time was determined by measuring the volume of fuel consumed during plowing time. It was calculated using the fuel meter equipment as shown in Figure (3) the length of line which marked by the marker tool on the paper sheet represents the fuel consumption. The fuel meter was calibrated prior and the volume of fuel was determined accurately.
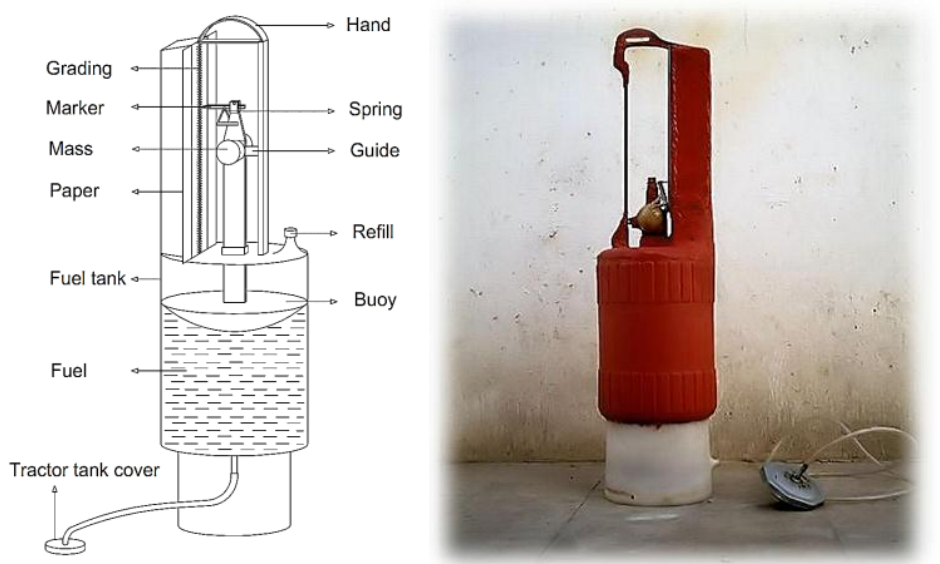

Figure (3): Fuel meter for measuring fuel consumption. 


\title{
8. Tractor wheel slip.
}

Slip percentages were calculated using the standard method of measuring distances traveled with and without load for a certain number of wheel revolutions.

\section{Total cost of performing a preparing operation}

Total hourly cost was determined according to EL-Awady (1978) as follows:

$$
\mathbf{C}=\left(\frac{\mathbf{p}}{\mathbf{h}}\right) *\left(\frac{\mathbf{1}}{\mathbf{L}}+\frac{\mathbf{i}}{\mathbf{2}}+\mathbf{t}+\mathbf{r}\right)+(\mathbf{1 . 2} * \mathbf{R F C} * \mathbf{f})+\left(\frac{\mathbf{m}}{\mathbf{1 4 4}}\right)+\left(\frac{\mathbf{P}_{\mathbf{1}}}{\mathbf{h}_{\mathbf{1}}}\right) *\left(\frac{\mathbf{1}}{\mathbf{L}_{\mathbf{1}}}+\frac{\mathbf{i}}{\mathbf{2}}+\mathbf{t}+\mathbf{r}_{\mathbf{1}}\right) \ldots \ldots \ldots \ldots
$$

\section{$\underline{\text { where }}$}

C: Hourly cost, (L.E./h).

p: Initial price of the tractor,(L.E).

h: Yearly working hours of tractor. (h/year).

L: Life expectancy of the tractor (year).

t: Annual taxes and overheads ratio, $(\%)$.

f: Fuel price, (L.E./L).

m: The monthly average wage,(L.E./month).

1.2: Factor accounting for lubrications.

RFC: Actual rate of fuel consumption, $(\mathrm{L} / \mathrm{h})$.

i: Annual interest rate,

$(\%)$. r: Annual repairs and maintenance ratiofor tractor, $(\%)$

$\mathbf{P}_{\mathbf{1}}$ :Initial price of machine, (L.E)

$\mathbf{h}_{\mathbf{1}}$ :Yearly working hours of machine, (h/year)

$\mathbf{r}_{1}$ :Annual repairs and maintenance ratiofor machine, $(\%)$

144: Operator monthly average working hours, (h) and

$\mathbf{L}_{\mathbf{1}}$ : Life expectancy of machine, (year)

\section{Total cost per unit area}

Total cost per unit area was determined as follows:

$\mathbf{T}_{\mathrm{ca}}=\mathbf{C} / \mathbf{A}_{\mathrm{f}}$

where;

Tca: Total cost of unit area,

(L.E./fed).

$\mathbf{A}_{\text {fc }}$ : Actual field capacity,

(Fed/h), and

C : Hourly cost,

(L.E./h).

11. Specific cost of production

Specific cost of production was determined as follows:

$\mathbf{S C P}=\mathbf{T C A} / \mathbf{Y}$

where;

SEC : Specific cost of production,

(L.E/Mg).

TCA: Total cost per unit area,

Y : Crop yield,

\author{
(L.E/fed), and. \\ (ton/fed).
}

\section{Results And Discussion}

The obtained were demonstrated and discussed as follows:

\section{1- Effect of different seed-bed preparation treatments on soil bulk density, soil porosity, soil penetration resistant and mean weight diameter (M.W.D.):}

The data shown in Table (2) indicated that the lowest values of soil bulk density, soil penetration resistant and M.W.D (1.12g.cm $\mathrm{cm}^{-3}, 360 \mathrm{kPa}$ and $\left.4.5 \mathrm{~mm}\right)$ were obtained at the plowing depths of $25 \mathrm{~cm}$ and forward speed $5 \mathrm{~km} . \mathrm{h}^{-1}$ with injection liquid organic material, while the highest values of them $\left(1.5 \mathrm{~g} . \mathrm{cm}^{-3}, 1090 \mathrm{kPa}\right.$ and $10.3 \mathrm{~mm}$ ) were obtained at the plowing depths of $15 \mathrm{~cm}$ and forward speed $3 \mathrm{~km} . \mathrm{h}^{-1}$ without organic material. It is clear also, that the reduction of the soil bulk density, soil penetration resistant and M.W.D were much more with injection liquid organic material compared with the others two methods of adding liquid organic material to the soil where the average of decreasing percentage after tillage compared with before tillage for soil bulk density, soil penetration resistant and M.W.D at three methods of adding organic material were (22, 53 and $40 \%$ for spraying method,25, 57 and 48\% for injection method and 19, 50 and 39\% for no-adding method)respectively. The data indicated that the highest values of relative reduction of soil bulk density, soil penetration resistant and M.W.D (36\%, 79\% and 68.5\%) respectively, were obtained at plowing depths of $25 \mathrm{~cm}$ and forward speed $\left(5 \mathrm{~km} \cdot \mathrm{h}^{-1}\right)$ with injection organic material, while the lowest values of soil bulk density, soil penetration resistant and M.W.D $(6 \%, 22 \%$ and $18.9 \%)$ respectively, were obtained at plowing depths of $15 \mathrm{~cm}$ and forward speed $\left(3 \mathrm{~km} \cdot \mathrm{h}^{-1}\right)$ without organic material. At all plowing depths, the relative reduction of soil bulk density, soil penetration resistant and M.W.D were increased with increasing the forward speed of the chisel plow and this resulted in decreasing due to the fact that lower forward speed of chisel plow decreased the soil mean diameter. On other hand, using chisel plow at high forward speeds stirs, pulverizes, crumbs and increases the soil distribution volume much more than using it with lower forward speeds. These results are agreed with the 
obtained results by Metwalli et al. (2000).Soil porosity values increased after all seed-bed preparation treatments than those before treatments. It is clear, that the soil porosity shows a reverse behavior as compared with the changes in soil bulk density at all seedbed preparation treatments. For every tillage depth, the soil porosity and its relative reduction were increased by increasing the forward speed of the chisel plow. These results are in agreement with Abdel-Aal et al. (2005).The results also showed that the increasing of the soil porosity was much more with injection liquid organic material compared with the others two methods of adding liquid organic material to the soil where the average of increasing percentage after tillage compared with before tillage for soil porosity at three methods of adding organic material (spraying, injection and no-adding) were (38\%, 45\% and 33\%) respectively.

Table (2): Effect of different seed-bed preparation treatments on some soil physical properties.

\begin{tabular}{|c|c|c|c|c|c|c|c|c|c|c|c|c|c|c|}
\hline \multicolumn{3}{|c|}{ Treatments } & \multicolumn{3}{|c|}{ Soil bulk density } & \multicolumn{3}{|c|}{ Soil porosity } & \multicolumn{3}{|c|}{$\begin{array}{l}\text { Soil penetration } \\
\text { resistant }\end{array}$} & \multicolumn{3}{|c|}{$\begin{array}{c}\text { Mean weight } \\
\text { diameter (M.W.D) }\end{array}$} \\
\hline 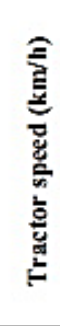 & 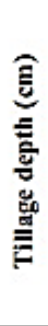 & 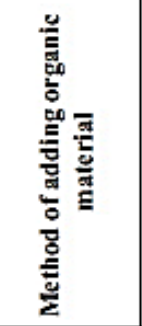 & 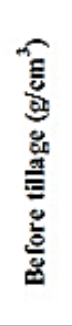 & 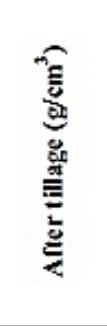 & 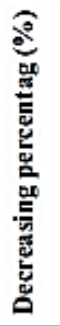 & 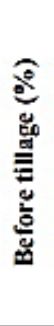 & 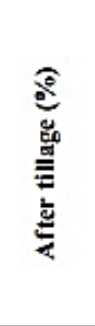 & 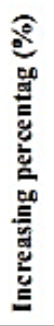 & 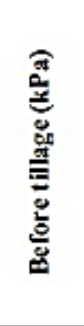 & 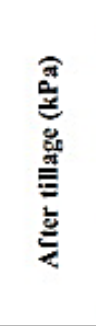 & 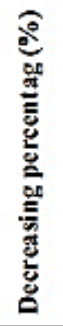 & 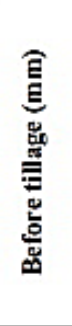 & 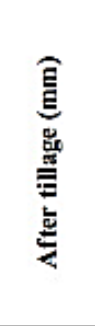 & 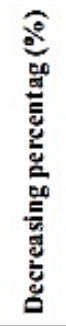 \\
\hline \multirow{6}{*}{3} & \multirow{3}{*}{15} & Spraying & \multirow{3}{*}{1.6} & $1.44^{\mathrm{B}}$ & 10 & \multirow{3}{*}{40} & $45^{\mathrm{FG}}$ & 13 & \multirow{3}{*}{1400} & $1050^{\mathrm{B}}$ & 25 & \multirow{3}{*}{12.7} & $10.1^{\mathrm{B}}$ & 20.5 \\
\hline & & Injection & & $1.39^{c}$ & 13 & & $48^{\text {DEFG }}$ & 20 & & $980^{\mathrm{c}}$ & 30 & & $9.3^{\mathrm{D}}$ & 26.8 \\
\hline & & No adding & & $1.5^{\wedge}$ & 6 & & $43^{\mathrm{G}}$ & 8 & & $1090^{\Lambda}$ & 22 & & $10.3^{\wedge}$ & 18.9 \\
\hline & \multirow{3}{*}{25} & Spraying & \multirow{3}{*}{1.74} & $1.37^{\mathrm{CD}}$ & 21 & \multirow{3}{*}{34} & $48^{\text {DEFG }}$ & 41 & \multirow{3}{*}{1740} & $900^{\mathrm{E}}$ & 48 & \multirow{3}{*}{14.3} & $9.4^{\mathrm{CD}}$ & 34.3 \\
\hline & & Injection & & $1.31^{\mathrm{EFG}}$ & 25 & & $51^{\mathrm{BCDE}}$ & 50 & & $850^{\mathrm{F}}$ & 51 & & $8.5^{\mathrm{F}}$ & 40.6 \\
\hline & & No adding & & $1.41^{\mathrm{BC}}$ & 19 & & $46^{\mathrm{EFG}}$ & 35 & & $930^{\mathrm{D}}$ & 47 & & $9.5^{c}$ & 33.6 \\
\hline \multirow{6}{*}{4} & \multirow{3}{*}{15} & Spraying & \multirow{3}{*}{1.6} & $1.33^{\mathrm{DE}}$ & 17 & \multirow{3}{*}{40} & $50^{\mathrm{CDEF}}$ & 25 & \multirow{3}{*}{1400} & $800^{G}$ & 43 & \multirow{3}{*}{12.7} & $8.7^{\mathrm{E}}$ & 31.5 \\
\hline & & Injection & & $1.28^{\mathrm{FGH}}$ & 20 & & $52^{\mathrm{BCD}}$ & 30 & & $730^{\mathrm{H}}$ & 48 & & $7.6^{\mathrm{H}}$ & 40.2 \\
\hline & & No adding & & $1.38^{c}$ & 14 & & $48^{\text {DEFG }}$ & 20 & & $840^{\mathrm{F}}$ & 40 & & $8.8^{\mathrm{E}}$ & 30.7 \\
\hline & \multirow{3}{*}{25} & Spraying & \multirow{3}{*}{1.74} & $1.27^{\mathrm{GHI}}$ & 27 & \multirow{3}{*}{34} & $52^{\mathrm{BCD}}$ & 53 & \multirow{3}{*}{1740} & $660^{3}$ & 62 & \multirow{3}{*}{14.3} & $7.7^{\mathrm{H}}$ & 46.2 \\
\hline & & Injection & & $1.23^{\mathrm{UK}}$ & 29 & & $54^{\wedge \mathrm{BC}}$ & 59 & & $600^{K}$ & 66 & & $6.4^{3}$ & 55.2 \\
\hline & & No adding & & $1.32^{\mathrm{EF}}$ & 24 & & $50^{\mathrm{CDEF}}$ & 47 & & $710^{1}$ & 59 & & $7.9^{\mathrm{G}}$ & 44.8 \\
\hline \multirow{6}{*}{5} & & Spraying & \multirow{3}{*}{1.6} & $1.22^{\mathrm{JK}}$ & 24 & \multirow{3}{*}{40} & $54^{\wedge \mathrm{BC}}$ & 35 & \multirow{3}{*}{1400} & $530^{\mathrm{M}}$ & 62 & & $6.9^{1}$ & 45.7 \\
\hline & 15 & Injection & & $1.17^{\mathrm{LM}}$ & 27 & & $56^{\wedge \mathrm{B}}$ & 40 & & $490^{\mathrm{N}}$ & 65 & 12.7 & $5.7^{\mathrm{K}}$ & 55.1 \\
\hline & & No adding & & $1.26^{\mathrm{HV}}$ & 21 & & $52^{\mathrm{BCD}}$ & 30 & & $570^{\mathrm{L}}$ & 59 & & $7^{1}$ & 44.9 \\
\hline & & Spraying & & $1.15^{\mathrm{MN}}$ & 34 & & $56^{\mathrm{AB}}$ & 65 & & $420^{P}$ & 76 & & $5.3^{\mathrm{M}}$ & 62.9 \\
\hline & 25 & Injection & 1.74 & $1.12^{\mathrm{N}}$ & 36 & 34 & $58^{\wedge}$ & 71 & 1740 & $360^{\circ}$ & 79 & 14.3 & $4.5^{\mathrm{N}}$ & 68.5 \\
\hline & & No adding & & $1.2^{\mathrm{KL}}$ & 31 & & $54^{\mathrm{ABC}}$ & 59 & & $460^{\circ}$ & 74 & & $5.5^{\mathrm{L}}$ & 61.5 \\
\hline L.S. & & t level 0.05 & & 0.04913 & & & 5.32155 & & & 13.10149 & & & 0.161342 & \\
\hline
\end{tabular}

\section{2- Effect of different seed-bed preparation treatments on actual field capacity, field efficiency, tractor slippage, fuel consumption and power requirements:}

From the results in Table (3), it is clear that the actual field capacity decreased by increasing the plowing depth. On the other hand, it increased by increasing the forward speed of the chisel plow in all plowing depths. The highest value of actual field capacity $\left(1.2 \mathrm{fed} \cdot \mathrm{h}^{-1}\right)$ was obtained at the lowest plowing depth $(15 \mathrm{~cm})$ and highest forward speed $\left(5 \mathrm{~km} \cdot \mathrm{h}^{-1}\right)$, while the lowest value $\left(0.6 \mathrm{fed} \cdot \mathrm{h}^{-1}\right)$ was obtained at the highest plowing depth $(25 \mathrm{~cm})$ and lowest forward speed $\left(3 \mathrm{~km} \cdot \mathrm{h}^{-1}\right)$. Actual field capacity achieved more increased with treatment of injection organic material compared with spraying and no-adding organic material where, the average of increasing percentage for injection method compared with spraying and no-adding methods were (8 and 18\%) respectively. Table (3); showed that the field efficiency was decreased by increasing both plowing depth and the forward speed of the chisel plow. The highest field efficiency (83\%) was obtained at the lowest plowing depth $(15 \mathrm{~cm})$ and lowest forward speed $\left(3 \mathrm{~km} \cdot \mathrm{h}^{-1}\right)$, while the lowest field efficiency $(45 \%)$ was obtained at the highest plowing depth $(25 \mathrm{~cm})$ and highest forward speed $\left(5 \mathrm{~km} \cdot \mathrm{h}^{-1}\right)$.Field efficiency showed more increased with treatment of injection organic material compared with spray and no adding organic material where, the average of increasing percentage for injection method compared with spraying and no-adding methods were (6 and 17\%) respectively. Tractor slippage, fuel consumption and power required to pulling chisel plow were measured for all mechanical operations of seedbed preparation, while power required to inject organic material with chisel 
plow was calculated for all mechanical operations for seed-bed preparation. Table (3), shows that the lowest tractor slippage, fuel consumption and power required to pulling chisel plow $\left(7.5 \%, 6.5 \mathrm{~L} \cdot \mathrm{h}^{-1}\right.$ and $\left.3.4 \mathrm{~kW}\right)$ were measured at the lower plowing depth $(15 \mathrm{~cm})$ with the lower forward speed $\left(3 \mathrm{~km} \cdot \mathrm{h}^{-1}\right)$ with injection organic material, while the highest value of tractor slippage, fuel consumption and power required to pulling chisel plow $\left(19.8 \%, 16.6 \mathrm{~L} \cdot \mathrm{h}^{-1}\right.$ and $\left.28.4 \mathrm{~kW}\right)$ were obtained at the higher plowing depth $(25 \mathrm{~cm})$ and the higher forward speed $\left(5 \mathrm{~km} \cdot \mathrm{h}^{-1}\right)$ without organic material. It is clear that the tractor slippage, fuel consumption and power required to pulling chisel plow increased by increasing both of the plowing depth and the forward speed of the chisel plow. On other hand, the tractor slippage, fuel consumption and power required to pulling chisel plow were more improved with injection organic material than the spraying and no-adding organic material where, the average of decreasing percentage for injection method compared with spraying and no-adding methods for tractor slippage, fuel consumption and power required to pulling chisel plow were (21 and 21\%), (16 and 17\%) and (23 and $25 \%$ ) respectively. Table (3) showed that the power required to inject organic material with chisel plow was decreased by increasing plowing depth and increased by increasing forward speed. The highest plowing depth $(25 \mathrm{~cm})$ with the lowest forward speed $\left(3 \mathrm{~km} \cdot \mathrm{h}^{-1}\right)$ was achieved the lowest value of power required to inject organic material with chisel plow $(0.8 \mathrm{~kW})$, but the highest value of power required to inject organic material $(1.3 \mathrm{~kW})$ was obtained at the lower plowing depth $(15 \mathrm{~cm})$ with the higher forward speed $\left(5 \mathrm{~km} \cdot \mathrm{h}^{-1}\right)$. On the other hand the results indicator to power required to inject organic material with chisel plow take the same conduct of actual field capacity where, the power required to inject organic material calculated by calculating the actual charge for injection operation according to actual field capacity corresponding of each study treatment. In general, the results clear that the value of total power requirements achieved much more significant decreased with adding liquid organic material by injection method at all levels of tillage depth and forward speed where, the average of decreasing percentage for injection method compared with spraying and no-adding methods were (23 and 19\%) respectively.

Table (3): Effect of different seed-bed preparation treatments on performance rate and power requirements of chisel plow.

\begin{tabular}{|c|c|c|c|c|c|c|c|c|c|c|}
\hline \multicolumn{3}{|c|}{$\begin{array}{l}\text { Measurements } \\
\text { Treatments }\end{array}$} & \multirow[b]{2}{*}{ 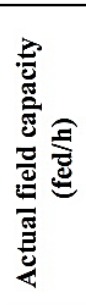 } & \multirow[b]{2}{*}{ 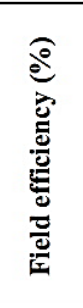 } & \multirow[b]{2}{*}{ 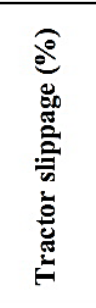 } & \multirow{2}{*}{ 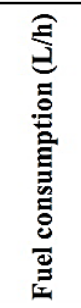 } & \multicolumn{4}{|c|}{ Power requirements $(\mathrm{kW})$} \\
\hline 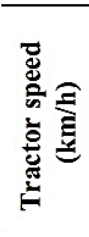 & 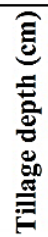 & 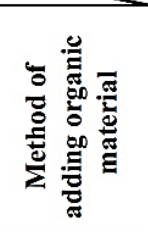 & & & & & 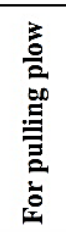 & 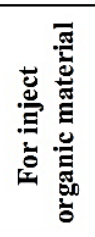 & 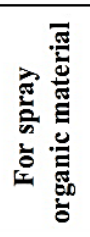 & 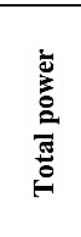 \\
\hline \multirow{6}{*}{3} & \multirow{3}{*}{15} & Spraying & $0.82^{\mathrm{GH}}$ & $77^{\mathrm{AB}}$ & $10^{\mathrm{K}}$ & $9.2^{\mathrm{HI}}$ & 7.5 & - & 1.2 & $8.7^{\mathrm{N}}$ \\
\hline & & Injection & $0.89^{\mathrm{EF}}$ & $83^{\mathrm{A}}$ & $7.5^{\mathrm{M}}$ & $6.5^{\mathrm{J}}$ & 3.4 & 1 & - & $4.4^{\mathrm{Q}}$ \\
\hline & & No adding & $0.76^{\mathrm{HIJ}}$ & $71^{\mathrm{BC}}$ & $11^{\mathrm{J}}$ & $9.4^{\mathrm{HI}}$ & 7.8 & - & - & $7.8^{\mathrm{P}}$ \\
\hline & \multirow{3}{*}{25} & Spraying & $0.64^{\mathrm{KL}}$ & $60^{\mathrm{EFGH}}$ & $15.1^{\mathrm{DEF}}$ & $11.5^{\mathrm{E}}$ & 14.5 & - & 1.2 & $15.7^{\mathrm{H}}$ \\
\hline & & Injection & $0.7^{\mathrm{JK}}$ & $66^{\mathrm{CDE}}$ & $12.2^{1}$ & $9.7^{\mathrm{H}}$ & 10.8 & 0.8 & - & $11.6^{\mathrm{L}}$ \\
\hline & & No adding & $0.6^{\mathrm{L}}$ & $57^{\mathrm{FGHI}}$ & $15.8^{\mathrm{DE}}$ & $11.6^{\mathrm{E}}$ & 14.7 & - & - & $14.7^{\mathrm{I}}$ \\
\hline \multirow{6}{*}{4} & \multirow{3}{*}{15} & Spraying & $1.02^{\mathrm{CD}}$ & $71^{\mathrm{BC}}$ & $13.3^{\mathrm{H}}$ & $10.5^{\mathrm{G}}$ & 10.8 & - & 1.2 & $12^{\mathrm{K}}$ \\
\hline & & Injection & $1.07^{\mathrm{BC}}$ & $75^{\mathrm{B}}$ & $9^{\mathrm{L}}$ & $9^{1}$ & 7 & 1.18 & - & $8.18^{\circ}$ \\
\hline & & No adding & $0.9^{\mathrm{EF}}$ & $63^{\text {DEF }}$ & $14^{\mathrm{GH}}$ & $10.7^{\mathrm{G}}$ & 11.3 & - & - & $11.3^{\mathrm{M}}$ \\
\hline & \multirow{3}{*}{25} & Spraying & $0.77^{\mathrm{HI}}$ & $54^{\mathrm{HIJK}}$ & $17^{\mathrm{C}}$ & $13.7^{\mathrm{C}}$ & 20 & - & 1.2 & $21.2^{\mathrm{D}}$ \\
\hline & & Injection & $0.86^{\mathrm{FG}}$ & $60^{\mathrm{EFGH}}$ & $14.6^{\mathrm{FG}}$ & $11.4^{\mathrm{EF}}$ & 16.5 & 0.95 & - & $17.4^{\mathrm{F}}$ \\
\hline & & No adding & $0.72^{\mathrm{IJ}}$ & $50^{\mathrm{JKL}}$ & $18^{\mathrm{B}}$ & $13.7^{\mathrm{C}}$ & 20.2 & - & - & $20.2^{\mathrm{E}}$ \\
\hline & \multirow{3}{*}{15} & Spraying & $1.09^{\mathrm{B}}$ & $61^{\mathrm{DEFG}}$ & $15^{\mathrm{EF}}$ & $12.2^{\mathrm{D}}$ & 15.3 & - & 1.2 & $16.5^{\mathrm{G}}$ \\
\hline & & Injection & $1.2^{\mathrm{A}}$ & $67^{\mathrm{CD}}$ & $11.7^{\mathrm{IJ}}$ & $10.9^{\mathrm{FG}}$ & 11.2 & 1.3 & - & $12.5^{\mathrm{J}}$ \\
\hline & & No adding & $1^{\mathrm{D}}$ & $56^{\mathrm{GHIJ}}$ & $15.5^{\mathrm{DEF}}$ & $12.4^{\mathrm{D}}$ & 15.7 & - & - & $15.7^{\mathrm{H}}$ \\
\hline & \multirow{3}{*}{25} & Spraying & $0.86^{\mathrm{FG}}$ & $48^{\mathrm{KL}}$ & $19^{\mathrm{A}}$ & $16.4^{\mathrm{A}}$ & 27.8 & - & 1.2 & $29^{\mathrm{A}}$ \\
\hline & & Injection & $0.93^{\mathrm{E}}$ & $52^{\mathrm{IJK}}$ & $16^{\mathrm{D}}$ & $14.6^{\mathrm{B}}$ & 24.8 & 1.05 & - & $25.8^{\mathrm{C}}$ \\
\hline & & No adding & $0.8^{\mathrm{GH}}$ & $45^{\mathrm{L}}$ & $19.8^{\mathrm{A}}$ & $16.6^{\mathrm{A}}$ & 28.4 & - & - & $28.4^{\mathrm{B}}$ \\
\hline \multicolumn{3}{|c|}{ L.S.D at significant level 0.05} & \begin{tabular}{|l}
0.0683 \\
\end{tabular} & 6.3427 & 0.9428 & 0.5024 & - & - & - & 0.1629 \\
\hline
\end{tabular}

\section{3- Effect of different seed-bed preparation treatments on wheat grain yield and specific cost of production.}

Table (4), clear that there is a significant effect for seed-bed preparation treatments on the grains yield and the specific cost of production. The highest grains yield $\left(3.1\right.$ ton.fed $\left.^{-1}\right)$ was obtained by using forward speed 
of $5 \mathrm{~km} \cdot \mathrm{h}^{-1}$ at $25 \mathrm{~cm}$ plowing depth, but the lowest grains yield $\left(1.43 \mathrm{ton} \cdot \mathrm{fed}^{-1}\right)$ was obtained by using forward speed of $3 \mathrm{~km} . \mathrm{h}^{-1}$ at $15 \mathrm{~cm}$ plowing depth. Highest grain yield was obtained with injection organic material at all levels of plowing depth and forward speed than the other methods of adding organic material where, the average of increasing percentage for injection method compared with spraying and no-adding methods were (15 and $34 \%)$ respectively. In general adding organic material (root plus) increased wheat grain yield compared without adding it as showed in Table (4).The highest specific cost of production(55L.E.ton ${ }^{-1}$ ) was obtained by using forward speed of $3 \mathrm{~km} . \mathrm{h}^{-1}$ at $25 \mathrm{~cm}$ plowing depth, but the lowest specific cost of production(16L.E.ton $\left.{ }^{-1}\right)$ was obtained by using forward speed of $5 \mathrm{~km} \cdot \mathrm{h}^{-1}$ at $15 \mathrm{~cm}$ plowing depth. Lowest specific cost of production was obtained with injection organic material at all levels of plowing depth and forward speed than the other methods of adding organic material where, the average of increasing percentage for injection method compared with spraying and no-adding methods were (26 and $42 \%$ ) respectively. In general adding organic material (root plus) decreased specific cost of production compared without adding it as showed in Table (4).

Table (4): Effect of different seed-bed preparation treatments on wheat grain yield and specific cost of production.

\begin{tabular}{|c|c|c|c|c|}
\hline \multirow{2}{*}{\multicolumn{3}{|c|}{$\begin{array}{ll}\text { Treatments } & \text { Measurements } \\
\end{array}$}} & \multirow[b]{3}{*}{$\begin{array}{l}\text { Wheat grain } \\
\text { yield (ton/fed) }\end{array}$} & \multirow[b]{3}{*}{$\begin{array}{l}\text { Specific cost } \\
\text { of production } \\
\text { (L.E/ton) }\end{array}$} \\
\hline & & & & \\
\hline $\begin{array}{c}\text { Tractor } \\
\text { speed } \\
(\mathbf{k m} / \mathbf{h})\end{array}$ & $\begin{array}{c}\text { Tillage } \\
\text { depth (cm) }\end{array}$ & $\begin{array}{l}\text { Method of } \\
\text { adding } \\
\text { organic } \\
\text { material } \\
\end{array}$ & & \\
\hline \multirow{6}{*}{3} & \multirow{3}{*}{15} & Spraying & $1.61^{\mathrm{I}}$ & $37^{\mathrm{E}}$ \\
\hline & & Injection & $1.84^{\mathrm{GH}}$ & $27^{\mathrm{G}}$ \\
\hline & & No adding & $1.43^{\mathrm{J}}$ & $46^{\mathrm{B}}$ \\
\hline & \multirow{3}{*}{25} & Spraying & $1.9^{\mathrm{G}}$ & $43^{C}$ \\
\hline & & Injection & $2.1^{\mathrm{EF}}$ & $33^{\mathrm{F}}$ \\
\hline & & No adding & $1.6^{\mathrm{I}}$ & $55^{\mathrm{A}}$ \\
\hline \multirow{6}{*}{4} & \multirow{3}{*}{15} & Spraying & $2^{\mathrm{FG}}$ & $25^{\mathrm{H}}$ \\
\hline & & Injection & $2.23^{\mathrm{DE}}$ & $20^{\mathrm{IJ}}$ \\
\hline & & No adding & $1.72^{\mathrm{HI}}$ & $34^{\mathrm{F}}$ \\
\hline & \multirow{3}{*}{25} & Spraying & $2.1^{\mathrm{EF}}$ & $34^{\mathrm{F}}$ \\
\hline & & Injection & $2.5^{\mathrm{C}}$ & $24^{\mathrm{H}}$ \\
\hline & & No adding & $1.9^{\mathrm{G}}$ & $41^{D}$ \\
\hline \multirow{6}{*}{5} & \multirow{3}{*}{15} & Spraying & $2.3^{\mathrm{D}}$ & $21^{\mathrm{I}}$ \\
\hline & & Injection & $2.7^{\mathrm{B}}$ & $16^{\mathrm{K}}$ \\
\hline & & No adding & $2^{\mathrm{FG}}$ & $27^{\mathrm{G}}$ \\
\hline & \multirow{3}{*}{25} & Spraying & $2.6^{\mathrm{BC}}$ & $27^{\mathrm{G}}$ \\
\hline & & Injection & $3.1^{\mathrm{A}}$ & $19^{\mathrm{J}}$ \\
\hline & & No adding & $2.2^{\mathrm{DE}}$ & $34^{\mathrm{F}}$ \\
\hline \multicolumn{3}{|c|}{ L.S.D at significant level 0.05} & 0.16229 & 1.8417 \\
\hline
\end{tabular}

\section{Conclusion}

The obtained results can be summarized as follows:

1. Soil bulk density was decreased after all seed-bed preparation treatments as compared with that before treatments. The lowest value of soil bulk density $\left(1.12 \mathrm{~g} . \mathrm{cm}^{-3}\right)$ was obtained at the higher plowing depth $(25 \mathrm{~cm})$ with the higher forward speed $\left(5 \mathrm{~km} \cdot \mathrm{h}^{-1}\right)$, while the highest value $\left(1.5 \mathrm{~g} . \mathrm{cm}^{-3}\right)$ was obtained at the lower plowing depth $(15 \mathrm{~cm})$ with the lower forward speed $\left(5 \mathrm{~km} \cdot \mathrm{h}^{-1}\right)$.

2. The soil penetration resistance takes the same trend as the soil bulk density. Both of soil bulk density and soil penetration resistance were decreased with increasing both of plowing depth and forward speed. The lowest value of soil penetration resistance $(360 \mathrm{kPa})$ was obtained at plowing depth of $25 \mathrm{~cm}$ with the higher speed $\left(5 \mathrm{~km} \cdot \mathrm{h}^{-1}\right)$, while the highest value of it $(1090 \mathrm{kPa})$ was obtained at the lower plowing depth $(15 \mathrm{~cm})$ with the lower forward speed $\left(3 \mathrm{~km} \cdot \mathrm{h}^{-1}\right)$. 
3. The actual field capacity was decreased by increasing the plowing depth, but it was increased with increasing of forward speed at all plowing depths. Plowing depth of $15 \mathrm{~cm}$ with $5 \mathrm{~km} \cdot \mathrm{h}^{-1}$ forward speed gave the highest value of actual field capacity $\left(1.2 \mathrm{fed}^{-1} \mathrm{~h}^{-1}\right)$, while the lowest value of actual field capacity $\left(0.6\right.$ fed. $\left.\mathrm{h}^{-1}\right)$ was obtained at plowing depth of $25 \mathrm{~cm}$ with $3 \mathrm{~km} \cdot \mathrm{h}^{-1}$ forward speed.

4. The field efficiency was deceased by increasing both plowing depth and forward speed. Plowing depth of $15 \mathrm{~cm}$ with $3 \mathrm{~km} \cdot \mathrm{h}^{-1}$ forward speed gave the highest value of field efficiency (83\%), but the lowest value (45\%) was obtained at plowing depth of $25 \mathrm{~cm}$ with $5 \mathrm{~km} \cdot \mathrm{h}^{-1}$ forward speed.

5. Plowing depth of $15 \mathrm{~cm}$ with lower forward speed $\left(3 \mathrm{~km} \cdot \mathrm{h}^{-1}\right)$ consumed lowest value of fuel per hour $(6.5$ $\mathrm{L}^{-1} \mathrm{~h}^{-1}$ ) and required the lowest value of pulling power $(3.4 \mathrm{~kW})$, but plowing depth of $25 \mathrm{~cm}$ with higher forward speed $\left(5 \mathrm{~km} \cdot \mathrm{h}^{-1}\right)$ consumed the highest value of fuel $\left(16.6 \mathrm{~L} \cdot \mathrm{h}^{-1}\right)$ and required highest value of pulling power $(28.4 \mathrm{~kW})$.

6. Plowing depth of $25 \mathrm{~cm}$ with the forward speeds $\left(5 \mathrm{~km} \cdot \mathrm{h}^{-1}\right)$ gave the highest value of grain yields (3.1ton.fed..$^{-1}$ ) but the lowest value of specific cost of production obtained at plowing depth of $15 \mathrm{~cm}$ with the forward speeds $\left(5 \mathrm{~km} \cdot \mathrm{h}^{-1}\right)$.

7. The method of injection for liquid organic material achieved the pest result for all treatments of this study compared with spray method and no-adding organic material.

\section{Recommendations}

1. The use of chisel plow for plowing a sandy calcareous soil at depth of $25 \mathrm{~cm}$ with forward speed of $5 \mathrm{~km} \cdot \mathrm{h}^{-1}$ can be recommended for seedbed preparation and wheat yield production although it required high cost but the different between the cost at plowing depth $15 \mathrm{~cm}$ with forward speed $3 \mathrm{~km} \cdot \mathrm{h}^{-1}$ was more little compared with the high profit which obtained from increased the wheat grain yield at depth of $25 \mathrm{~cm}$ with forward speed of $5 \mathrm{~km} \cdot \mathrm{h}^{-1}$.

2. Using the method of injection with plowing as it is in this study can be recommended for inject liquid organic material (root plus) to the soil. Where this method achieved the high usefulness of increasing the effectiveness of liquid organic material at the same time improved the performance of chisel plow and reduced the power requirements.

\section{References}

[1]. Abdel-Aal, S. E., A. M. Kishta and A. Lotfy. 2005. Seedbed preparation and irrigation depths affecting soil physical properties and rice yield. Misr J.Agr. Eng., 22(2); 572-591.

[2]. American Society of Agricultural Engineers. 2004. Terminology and Definitions for Soil Tillage and Soil-Tool Relationships. ASAE Standards. ASAE EP291.2 FEB04.

[3]. Araya K. 1980. Pressure produced when fluid is introduced into soil layer under pressure. J. of JSAM, Hokkaido. 21:1-9.

[4]. Araya K. 1985. Pressure produced when fluid is introduced into soil layer under pressure. J. of JSAM, Hokkaido. No. 21: 1-9.

[5]. Araya K. 1985. Soil failure by introducing fluid under pressure. Proc. Of int. conf. of soil dynamics, 3, Auburn University, Auburn, Ala. Pp. 57-70.

[6]. Araya K. and K. Katianishi. 1981. Pressure produced when fluid is introduced under pressure into soil layer (111). J. of JSAM 43 (1): $19-29$

[7]. Araya K., K. Kawanishi and R. Goe. 1982 (a). Pressure produced when fluid is introduced under pressure into soil layer (IV). J. of JSAM 44 (2): 281-292

[8]. Black C. A. 1965. Methods of Soil Analysis. $1^{\text {st }}$ Edn, American Society Agronomy, Madison, WI., USA.

[9]. Chen B.C., L.Q.Ren, J.Q. Li and Q. X. Hu 1990. Study on the method of collecting the body surface liquid of earthworms. Transactions of the Chinese Society of Agricultural Engineering, 6: 7-12.

[10]. Chen Y. 2002. A liquid manure injection tool adapted to different soil conditions. Transactions of the ASAE 45(6): 1729-1736.

[11]. Chen Y. and S. Rahman. 1999. Design criteria and performance evaluation of a liquid manure injection tool for grassland. ASAE/CSAE Paper No MBSK99- 122. Saskatoon, SK: CSAE.

[12]. Chen Y., Q. Zhang and D.Petkau. 2000. Evaluation of different techniques for liquid manure application on grassland. CSAE Paper No AFL099. Saskatoon, SK: CSAE.

[13]. Collins B.A. and D.B. Fowler. 1996. Effect of soil characteristics, seeding depth, operating speed and opener design on draft force during direct seeding. Soi1 and Tillage Research 39: 199-211.

[14]. Collins B.A. and D.B. Fowler. 1996. Effect of soil characteristics, seeding depth, operating speed and opener design on draft force during direct seeding. Soi1 and Tillage Research 39: 199-211.

[15]. El-Awady M. N. 1978. Engineering of Tractor and Agricultural Machinery. Text Book, (in Arabic), Fac. Of Ag. Ain Shams Univ., Cairo, Egypt.

[16]. Hall L. E. 1986. Soil injection research in the UK. Efficient land use of sludge and manure. eds.Kofoed, A.D., J.H. Williams and P.L. 'Hermite, 78-89. Elsevier Applied Science Publishers, London: Elsevier.

[17]. Hilborn D. 2000. Choosing a liquid manure application method. In Proceedings from managing, Nutrients and Pathogens from Animal Agriculture, 380-394. Camp Hill. Pennsylvania, March 28-30.

[18]. Huijsmans J. F. M., J.G.L. Hendricks and G.D. Vermeulen. 1998. Draught requirement of trailing-foot and shallow injection equipment for applying slurry to grassland. Journal of Agricultural Engineering Research 71: 347-356.

[19]. IGER 1995. Research to Prevent Pollution. Institute of Grassland and Environmental Research. North Wyke, Okehampton. Devon EX20 2SB.

[20]. Jokela W. and D. Côté. 1994. Options for direct incorporation of liquid manure. In Proceedings Rom the Liquid Manure Application Systems Conference. 201-215. Rochester, New York. December 1-2.

[21]. Kempainen E. 1986. Effect of cattle slurry on quantity and quality of barley and grass yield. In Efficient Land Use of Sludge and 
Manure. eds. Kofoed, A.D., J.H. Williams, and P. L'Hermite, 64-72. Elsevier Applied Science Publishers. London.

[22]. Kepner R. A., R. Bainer and E. L. Barger. 1978. Principles of Farm Machinery. Ch 5, The AVI Publishing Company.

[23]. Kuzmich I. A., and M. A. Rutherberg. 1978. Investigation of the Interaction Between High Speed Waterjet and Cutter During Breakage of a Rock Mass," Fourth Int. Symp. on Jet Cutting, BHRA.

[24]. Laguë C. 1991. Design of a semi-liquid dairy cattle manure spreader/injector. Applied Engineering in Agriculture 7(6):655-660.

[25]. McKyes E., S. Negi, R.J. Godwin and J. R. Ogilvie. 1977. Design of a tool for injecting organic waste slurries in soil. Journal of Terramechanics $14:(3) 127-136$

[26]. Metwally M. E., R. R. Abou-Shieshaa, R. M. Kholief and R. E. Kanany. (2000). Effect of four different tillage systems and nitrogen sources on wheat production under improved salt affected soil. Misr J. Agric. Eng., 17(3): 539-554.

[27]. Misselbrook, T. J. Laws and B. Pain. 1996. Surface application and shallow injection of cattle slurry on grassland: nitrogen losses. Herbage yields and nitrogen recoveries. Grass and Forage Science 51 (1): 270-277.

[28]. Moodie K. 1976. Coal Ploughing Assisted with High Pressure Waterjets. Third International Symp. on Jet Cutting, BHRA, Chicago, U.S.A.

[29]. Negi S.C., E. McKyes, R.J. Godwin and J.R. Ogilvie. 1978. Design and performance of a liquid manure injector. Transactions of the ASAE 21(5): 963-971.

[30]. Prins W.H. and P.J.M. Snijders. 1987. Negative effects of animal manure on grassland due to surface spreading and injection. In van der Meer, H.G., R.J. Unwin, T.A. van Dijk and G.C.Ennil (eds.), Animal manure on Grassland and Fodder Crops. pp. 119-135. Dordrecht: MartinusNijhoff (cited by Misselbrook et al. 1996)

[31]. Qaisrani A. R. (1993). The effects of modified and unsmoothed surfaces on the draft of bulldozing plates and mouldboard plows. A Ph.D. Dissertation, Jilin University of Technology, Changchun, China.

[32]. Qaisrani A. R., B. C. Cen and L. Q. Ren 1992. Modified and unsmoothed surfaces - a means to reduce plowing resistance. Agricultural Engineering Journal, 1, 115-124.

[33]. Qlan D. H. and J. X.Zhang (1984). Research on adhesion and friction of soil against metallic materials. ActaAgromechanica, 15, 70-78.

[34]. Salokhe V. M., W. Cheunpakaranant and T. Niyampa 1999. Effects of enamel coating on the performance of tractor drawn rotavator. Journal of Terramechanic, 36, 127-138

[35]. Stafford. J.V. 1979. The performance of a rigid tine in relation to soil properties and speed. Journal of Agricultural Engineering Research 24: 41-56.

[36]. Van Bavel, C. M. 1949. Mean weight diameter of soil aggregates as a statistical index of aggregation. Soil Sci. Soc. Am. J. 14: 2023. 